\title{
PEMODELAN GEOLOGI BATUBARA \\ DAERAH MARANGKAYU KABUPATEN KUTAI KARTANEGARA MENGGUNAKAN COAL RESOURCES AND RESERVES EVALUATION SYSTEM
}

\author{
COAL GEOLOGY MODELLING \\ AT MARANGKAYU AREA, KUTAI KARTANEGARA REGENCY \\ BY USING COAL RESOURCES AND RESERVES \\ EVALUATION SYSTEM
}

\author{
Oleh: \\ Jimmy Dharmawan \\ Pusat Sumber Daya Geologi \\ JI. Soekarno Hatta No. 444 Bandung
}

\begin{abstract}
SARI
Pemodelan geologi batubara daerah Marangkayu, Kabupaten Kutai Kartanegara merupakan pengembangan dari pekerjaan penelitian batubara bersistem yang dilakukan oleh Pusat Sumber Daya Geologi setiap tahunnya, seluruh data hasil penelitian diproses menjadi basis data batubara dan dievaluasi, sehingga menghasilkan suatu interpretasi bawah permukaan tentang lapisan batubara, baik itu korelasi bentuk dan strukturnya. Pekerjaan pemodelan ini menggunakan perangkat lunak yang dihasilkan dari kerja sama antara NEDO (Jepang) dan Pusat Sumber Daya Geologi dan dinamai Coal Resources and Reserves Evaluation System (CRRES). Data hasil pemodelan merupakan data yang berbasis Sistem Informasi Geografis (SIG) dan hasilnya dapat diakses oleh berbagai pihak berdasarkan keperluan menurut tingkatan data melalui media internet. Pekerjaan pemodelan adalah pekerjaan dalam ruangan, hampir semua kegiatan pemodelan dilakukan di kantor. Hasil pemodelan dapat berubah sewaktu-waktu apabila ada penambahan data berupa lokasi titik bor baru, singkapan baru dan tatanan topografi baru.
\end{abstract}

Kata kunci: Marangkayu, CRRES, SIG, pemodelan geologi

\section{ABSTRACT}

Geological modeling on Marangkayu coal area in Kutai Kartanegara Regency was the follow-up process of systematical coal prospect mapping done by Center for Geological Resources annually, where all of the research results had been processed into one integrated coal database and evaluated, in order to produce various underground coal seam interpretation such as its correlation, form and structure. The modeling process was conducted with software application developed by joint study between NEDO (Japan) and Center for Geological Resources that called as CRRES. The result are data that based on Geographic Information System (GIS) format and can be access through the internet. The data access as based on its aim and level. The work was deskwork which most of time done in the office. The modeling result can change depend on more additional data such as new drillhole, outcrops and topographic shape.

Keywords : Marangkayu, CRRES, GIS, geological modeling 


\section{PENDAHULUAN}

Secara administratif daerah kajian termasuk wilayah Kecamatan Marangkayu, Kabupaten Kutai Kertanegara, Provinsi Kalimantan Timur (Gambar 1). Luas daerah kajian batubara daerah Marangkayu adalah 6.515 hektar.

Maksud dilakukannya pemodelan geologi daerah Marangkayu ini adalah untuk memanfaatkan perangkat lunak Coal Resources and Reserves Evaluation System (CRRES) hasil pengembangan pihak New Energy and Industrial Technology Development Organization (NEDO) Jepang dan Pusat Sumber Daya Geologi (PSDG) Badan Geologi. Tujuannya adalah menghitung sumber daya dan cadangan batubara daerah Marangkayu yang hasilnya disajikan dalam bentuk tiga dimensi berbasis Sistem Informasi Geografis (SIG).

Pemodelan geologi merupakan representasi bawah permukaan yang ditampilkan secara terkomputerisasi berdasarkan pengamatan geologi dan geofisika (Wikipedia, 2012). Pemodelan geologi ini mempergunakan antara lain data setara numerik, konfigurasi, korelasi, bentuk dan struktur lapisan batubara.

CRRES merupakan sistem terpadu yang mencakup proses alur kerja mulai dari pengumpulan data geologi hingga proses pendukung keputusan. CRRES juga mencakup fungsi kompleks seperti mengedit data spasial, query spasial, analisis spasial, memasukkan/menghapus/menyisipkan/me mutakhirkan data spasial, manajemen basis data dan fungsi sistem administrasi. CRRES juga memiliki server aplikasi web sebagai sub sistem yang berfungsi menyajikan data hasil pemodelan geologi dan evaluasi kepada publik.

Coal Mine Analyst (CMA) merupakan aplikasi yang diciptakan bersamaan dengan pembuatan CRRES, CMA dipakai untuk mengolah data yang ada dalam basis data menjadi model tiga dimensi yang sifat endapannya berlapis seperti lapisan batubara. CMA merupakan aplikasi yang digunakan pada proses evaluasi.

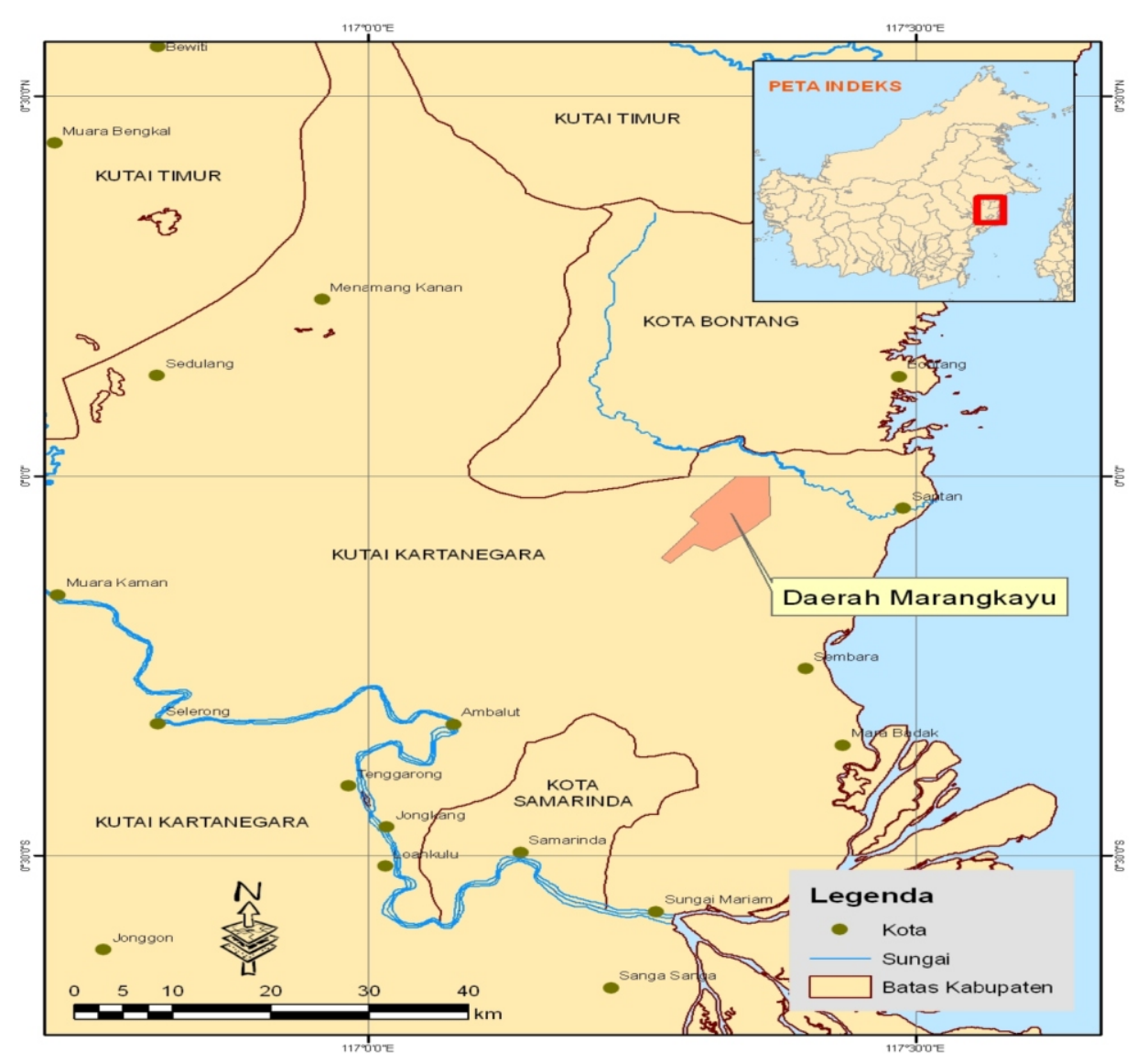

Gambar 1. Lokasi daerah pemodelan geologi batubara 
CMA merupakan aplikasi tambahan (plugin) pada program ArcGIS dan dibuat berdasarkan pada prinsip umum stratigrafi tentang urutan lapisan. Sesuai dengan prinsip stratigrafi tersebut, CMA membuat model lapisan batubara daerah kajian dengan mengikuti pola struktur yang mempengaruhi bentuk sehingga tidak saling berpotongan.

Data yang dipakai terdiri dari 11 data lubang bor, 110 data singkapan batubara dan data hasil laboratorium untuk 13 conto batubara.

\section{METODOLOGI}

Metode yang digunakan dalam pekerjaan iniadalah :

\section{Inventarisasi Data}

Pekerjaan inventarisasi data adalah mengumpulkan data yang akan dipakai dalam proses pemodelan yaitu data hasil eksplorasi daerah Marangkayu (Anonim, 2002). Selain data hasil eksplorasi, data pendukung lain yang dikumpulkan adalah data administratif, jalan, pemukiman, sungai dan tata guna lahan.

\section{Pembuatan Database (Form Database)}

Data yang diperoleh dari hasil penyelidikan batubara daerah Marangkayu kemudian dikelompokkan menjadi beberapa tabel pengisian. Uraian tiap tabel tersebut adalah sebagai berikut:

\section{Coal Seam Definition}

Tabel ini menjelaskan jumlah lapisan batubara (notasi ID) disertai nama tiap lapisannya (SeamName).

\section{Collar}

Tabel ini menjelaskan jumlah titik bor (BoreHoleName), nama titik bor, koordinat titik bor dalam meter ( $X$ untuk garis bujur dan Y untuk garis lintang), elevasi titik bor sengan satuan meter di atas permukaan laut (Z), total kedalaman dalam meter (TotalDepth), tahun pengeboran (Year Drilled) dan institusi yang melakukan pengeboran (Company).

\section{Litho}

Tabel ini berisi data nomor urut identifikasi lubang bor (SEQ NO), nama titik bor (BoreHoleName), from-to lapisan batuan, ketebalan tiap lapisan batuan (Thickness), kemiringan lapisan batuan (Dip), tipe batuan (RockType), nama lapisan batubara (SeamName), nama contoh batubara (Sample ID) dan komentar (Comment). Data from-to adalah data yang menjelaskan hasil rekaman ketebalan pada batuan hasil pemboran dalam meter untuk setiap tipe batuan dimana from adalah bagian atas lapisan (top) dan to adalah bagian bawah lapisan (bottom).

\section{Outcrop Location}

Tabel ini menjelaskan singkapan batubara berupa nama singkapan (Ourcrop No), koordinat lokasi singkapan ( $\mathrm{X}$ dan $\mathrm{Y}$ ), elevasi (Z), nilai arah jurus (Strike), kemiringan lapisan (Dip) serta tipe pengukuran singkapan (Type). Tipe pengukuran singkapan adalah pengukuran singkapan berdasarkan ketebalan lapisan batubara. Apabila top dan bottom dari suatu singkapan batubara terlihat jelas dan ketebalannya dapat diukur, maka termasuk tipe M1. Apabila ketebalan hanya dapat diukur dari top atau bottom saja maka termasuk tipe $\mathrm{M} 2$; sedangkan tipe U dimana ketebalan singkapan batubara tidak dapat dihitung.

\section{Outcrop Lithology}

Tabel ini sama seperti halnya tabel Litho akan tetapi terfokus hanya kepada singkapan batubara, terdiri dari nomor urut identifikasi singkapan (SEQ NO), nama singkapan (Outcrop No), from-to, ketebalan lapisan batubara (Thickness), kemiringan lapisan (Dip), tipe batuan (RockType), nama lapisan batubara (SeamName), tipe pengukuran singkapan (MeasureType) dimana pada prinsipnya sama dengan kolom penjelasan pada tabel Outcrop Location. Nilai From dan To harus memiliki nilai, hal ini untuk memudahkan sistem menggunakan data untuk proses perhitungan karena sistem tidak mentolerir data tanpa nilai (null); nama contoh batubara (Sample ID) dan komentar (Comment).

\section{Quality Original}

Tabel ini berisi seluruh data kualitas batubara sebelum dilakukan proses kalkulasi. Data tersebut berupa nama daerah pemodelan (AreaName), nama titik bor (BoreHoleName), nama lapisan batubara (Coal Seam), from-to pengambilan conto batubara, nama conto (Sample No), analisis proksimat yang terdiri dari dasar analisis $($ Basis $(P))$, kelembaban (M (\%)), kadar abu (A (\%)), zat terbang (Vol (\%)), Fixed Carbon (FC (\%)), total sulfur (Total S (\%)), nilai kalori $(\mathrm{CV}(\mathrm{kcal} / \mathrm{kg}))$, analisis ultimat dan petrografi. 
Tabel 1. Data korelasi lubang bor

\begin{tabular}{|c|c|c|c|c|}
\hline Lubang Bor & $\begin{array}{c}\text { Elevasi } \\
\text { (mdpl) }\end{array}$ & Kedalaman (m) & Ketebalan (m) & Nama Lapisan \\
\hline $\mathrm{BH}-07$ & 83 & $8,8-10,05$ & 1,25 & $\mathrm{~B} 10$ \\
\hline $\mathrm{BH}-04$ & 79 & $46,05-47$ & 0,95 & $\mathrm{~B} 9$ \\
\hline $\mathrm{BH}-05$ & 44 & $5,3-7,7$ & 2,4 & $\mathrm{~B} 9$ \\
\hline $\mathrm{BH}-06$ & 56 & $8-11,3$ & 3,3 & $\mathrm{~B} 9$ \\
\hline $\mathrm{BH}-03$ & 60 & $16-17,1$ & 1,1 & $\mathrm{~B} 6$ \\
\hline $\mathrm{BH}-08$ & 54 & $54-54,6$ & 0,6 & $\mathrm{~B} 3$ \\
\hline $\mathrm{BH}-02$ & 42 & $18,5-19,3$ & 0,8 & $\mathrm{~B} 3$ \\
\hline $\mathrm{BH}-02$ & 42 & $73,6-74,5$ & 0,9 & $\mathrm{~B} 2$ \\
\hline $\mathrm{BH}-01$ & 85 & $3-4,3$ & 1,3 & $\mathrm{P} 4$ \\
\hline $\mathrm{BH}-01$ & 85 & $69,9-70,8$ & 0,9 & $\mathrm{P} 3$ \\
\hline
\end{tabular}

$(\mathrm{mdpl})^{\star}$ meter dari permukaan laut

\section{Quality Calculation}

Tabel ini menjelaskan data kualitas batubara yang telah di kalkulasi (data komposit) dari tabel Quality Original. Dalam proses pemodelan, kolom ini yang akan digunakan untuk membuat peta isopach kualitas dari beberapa data pada tabel Quality Original. Untuk daerah Marangkayu tabel Quality Calculation sama dengan tabel Quality Originalkarena tidak adanya data ply sample.

\section{Verifikasi data}

Verifikasi data dilakukan untuk memastikan apakah data yang sudah dimasukkan ke basis data merupakan data sahih. Apabila tidak, maka bisa saja data tersebut tidak digunakan dalam proses pemodelan. Data yang di verifikasi mencakup seluruh data hasil eksplorasi dan data pendukung lain.

\section{HASIL DAN PEMBAHASAN}

Pada dasarnya pemodelan geologi dengan CRRES menitik beratkan pekerjaan pada perhitungan sumber daya dan cadangan batubara disertai dengan pembuatan data pendukung umum lainnya seperti korelasi lubang bor, peta struktur kontur lapisan batubara, peta geologi, peta isopach (ash, sulfur, thickness, moisture, calorie) hingga bentuk tiga dimensi (3D) bawah permukaan dari daerah Marangkayu. Proses pemodelan Sumber Daya dan Cadangan berdasarkan kepada Standar Nasional Indonesia (SNI) Nomor 13-60111999 tentang Klasifikasi Sumber Daya Cadangan Batubara.

\section{Korelasi Lubang Bor}

Terdapat 11 lokasi pengeboran di daerah ini. Dari hasil deskripsi satuan batuan tiap lubang bor didapati bahwa ada 8 lubang bor yang menembus tujuh lapisan batubara. Korelasi lubang bor ini bertujuan menghubungkan tiap lapisan batubara yang memiliki ciri, baik itu ciri batuan dan geologi yang sama dan dasar pengkorelasian lubang bor adalah elevasi dari lokasi tiap lubang bor (Gambar 2). Data korelasi lubang bor dapat dilihat pada Tabel 1 .

\section{Struktur Kontur Lapisan Batubara}

Daerah Marangkayu memiliki tujuh (7) lapisan batubara dengan ketebalan yang berbeda-beda. Ke-tujuh lapisan tersebut diberi nama B2, B3, B6, B9, B10, P3 dan P4. Struktur geologi yang berkembang pada daerah ini tidak mempengaruhi bentuk dan pelamparan lapisan batubara, sehingga tipe pemodelan struktur yang dipilih adalah simple (Gambar 3). Struktur kontur batubara dibuat dengan jarak $50 \mathrm{~m}$.

\section{Peta Geologi}

Peta geologi hasil pemodelan ini adalah perpaduan dari data sungai, lokasi singkapan, lokasi titik bor, garis kontur ketinggian, garis singkapan lapisan batubara, data infrastruktur seperti jalan dan desa (Gambar 4). Peta geologi yang dihasilkan CRRES berbeda dengan peta geologi pada umumnya dikarenakan tidak tersedianya sumber data seperti batas formasi batuan dan deskripsinya.

\section{Peta Isopach}

Peta isopach adalah peta yang 


\section{MAKALAH ILMIAH}
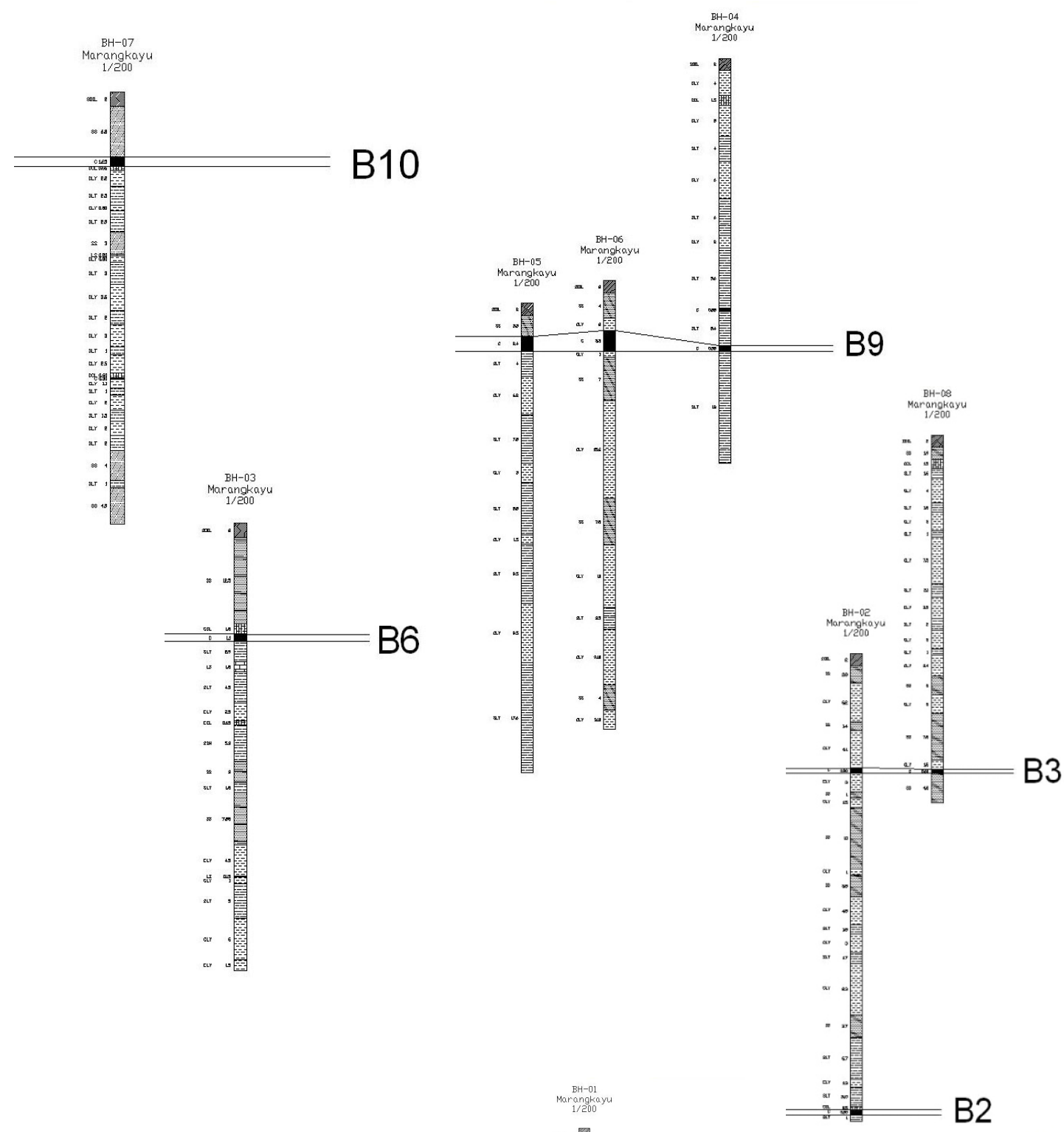

\section{P3}

Gambar 2. Korelasi lubang bor daerah Marangkayu 


\section{MAKALAH ILMIAH}

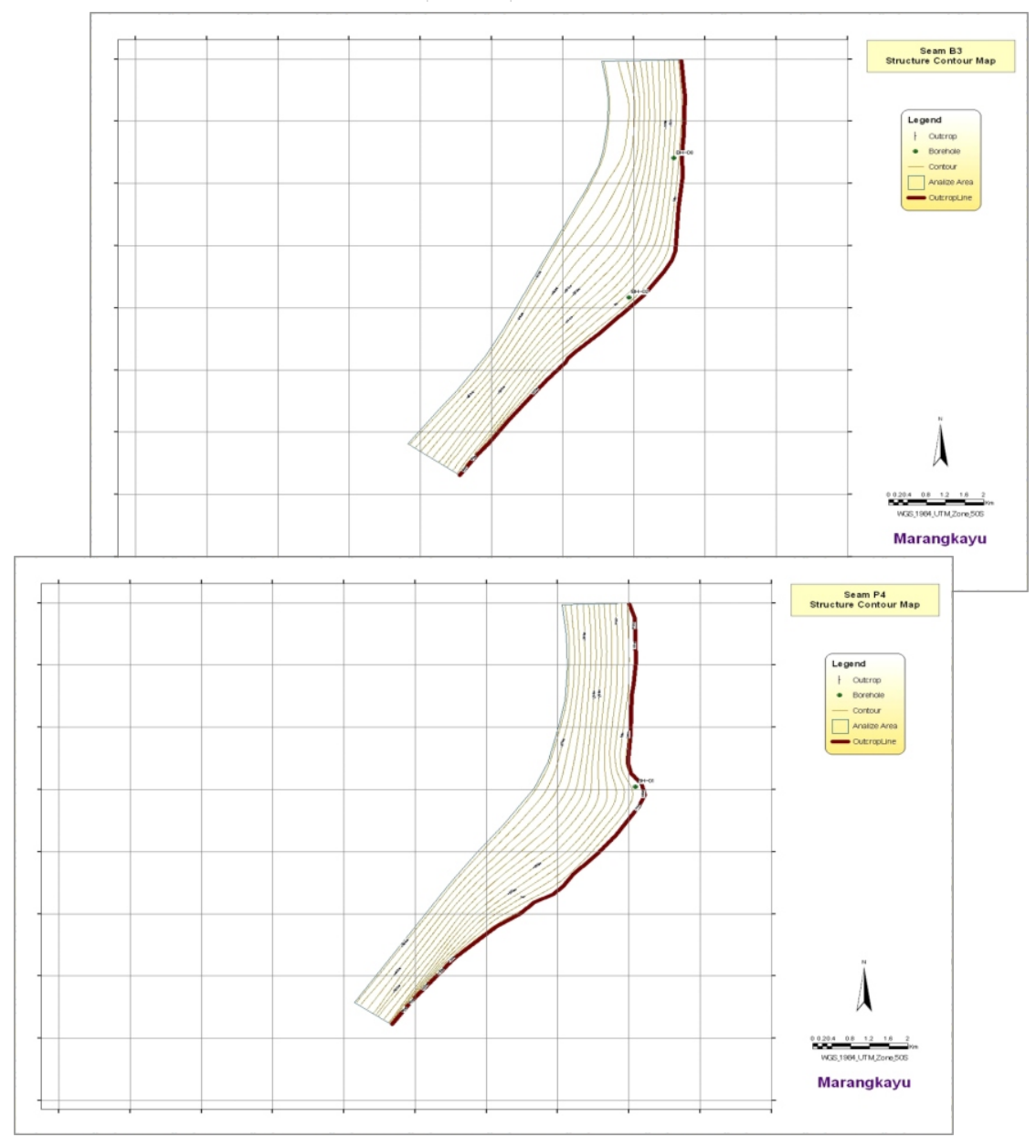

Gambar 3. Peta struktur kontour lapisan batubara B3 dan P4

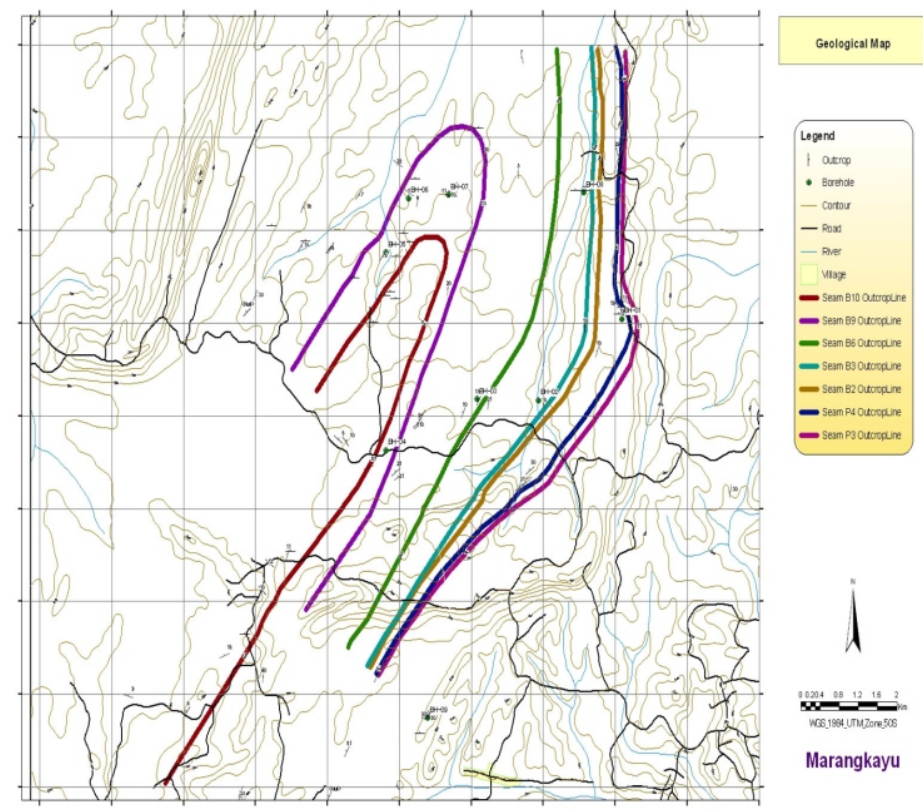

Gambar 4. Peta geologi daerah Marangkayu yang di hasikan oleh CRRES 


\section{MAKALAH ILMIAH}

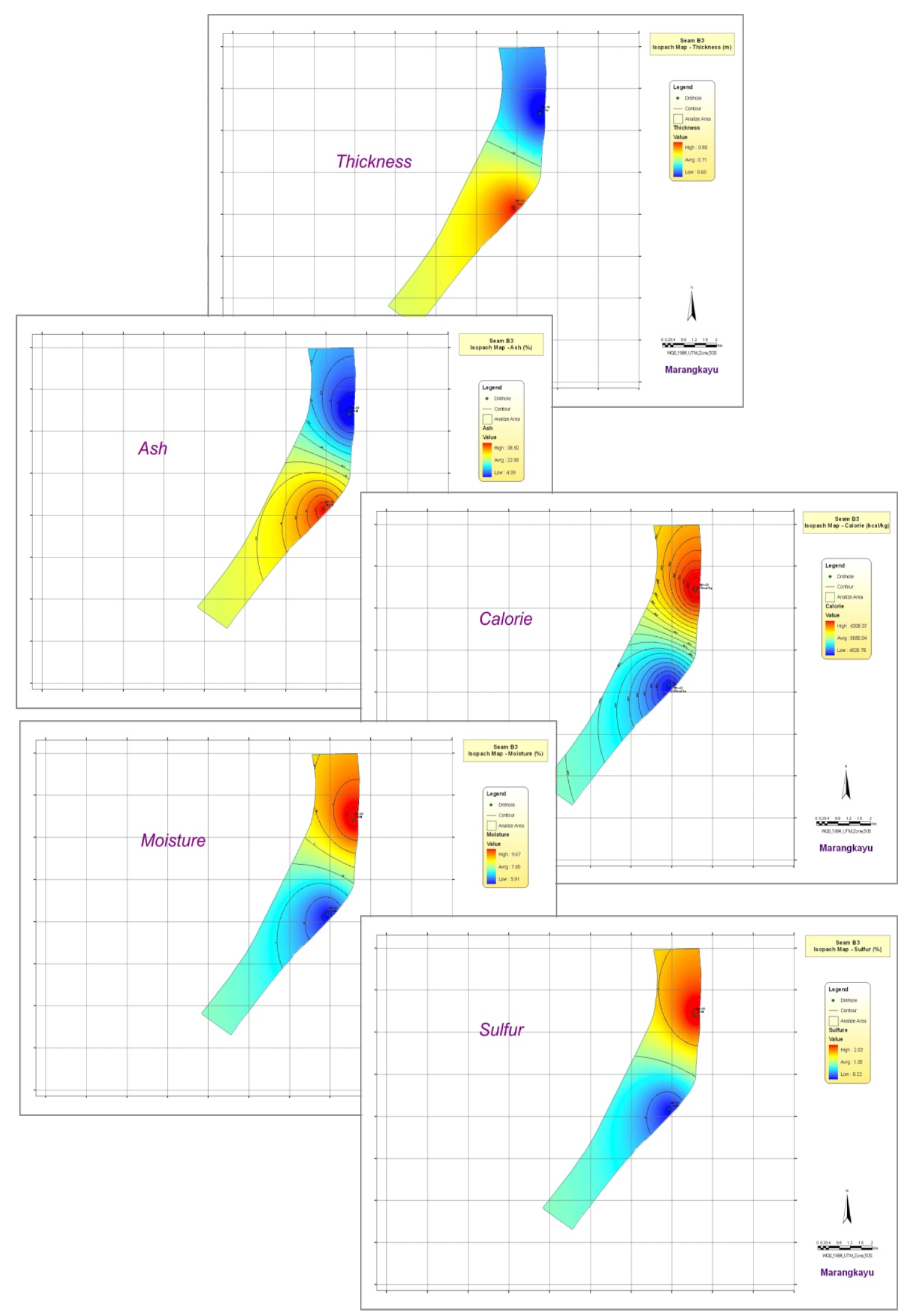

Gambar 5. Peta isopach lapisan batubara B3 


\section{Peta 3D BirdView}

Peta ini menggambarkan kondisi bawah permukaan daerah Marangkayu. Data yang digabungkan adalah data permukaan seperti topografi, sungai, singkapan serta data raster dari tiap lapisan batubara. Data 3D BirdView ini bersifat dinamis, dapat dimanipulasi menjadi data bergerak (video) sehingga gambaran bawah permukaan menjadi lebih nyata (Gambar 6).

\section{Peta Sumber Daya Batubara}

Peta sumber daya batubara yang dihasilkan dari pemodelan ini dibuat bedasarkan ketentuan yang diatur dalam Standar Nasional Indonesia (SNI) Nomor
13-6011-1999 tentang Klasifikasi Sumber Daya Cadangan Batubara untuk tiap daerah baik itu pada tingkatan Measured, Indicated, Inferred dan Assumption, dimana tingkat Assumption dapat disamakan dengan Hipotetik. Dalam peta ini juga disertakan daerah yang terbatas (Restricted Area) yang merupakan daerah tidak boleh ditambang karena memperhitungkan obyek seperti sungai utama, jalan dan pemukiman. Restricted Area tidak berdasarkan SNI melainkan kesepakatan internal PSDG yang memutuskan bahwa jarak buffer adalah 500 meter dari garis sisi terluar aliran sungai utama, jalan dan pemukiman (Gambar 7).

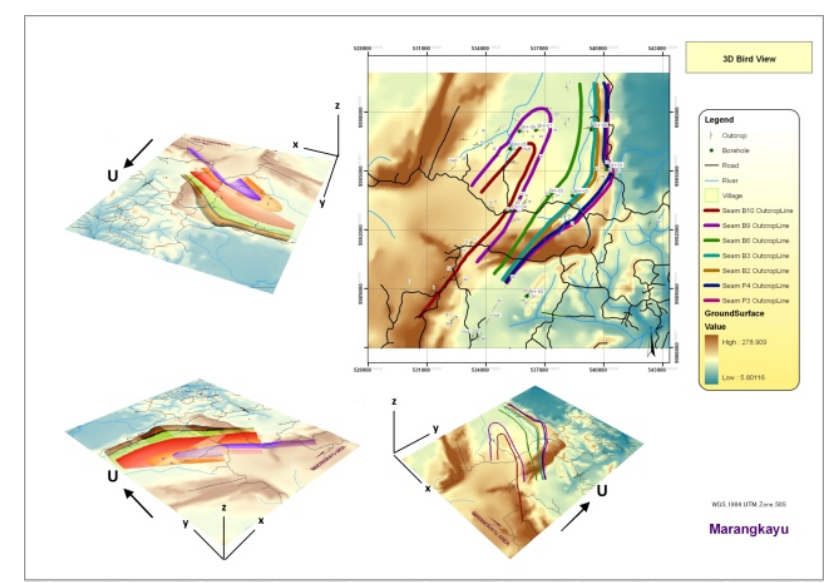

Gambar 6. Peta 3D BirdView Daerah Marangkayu

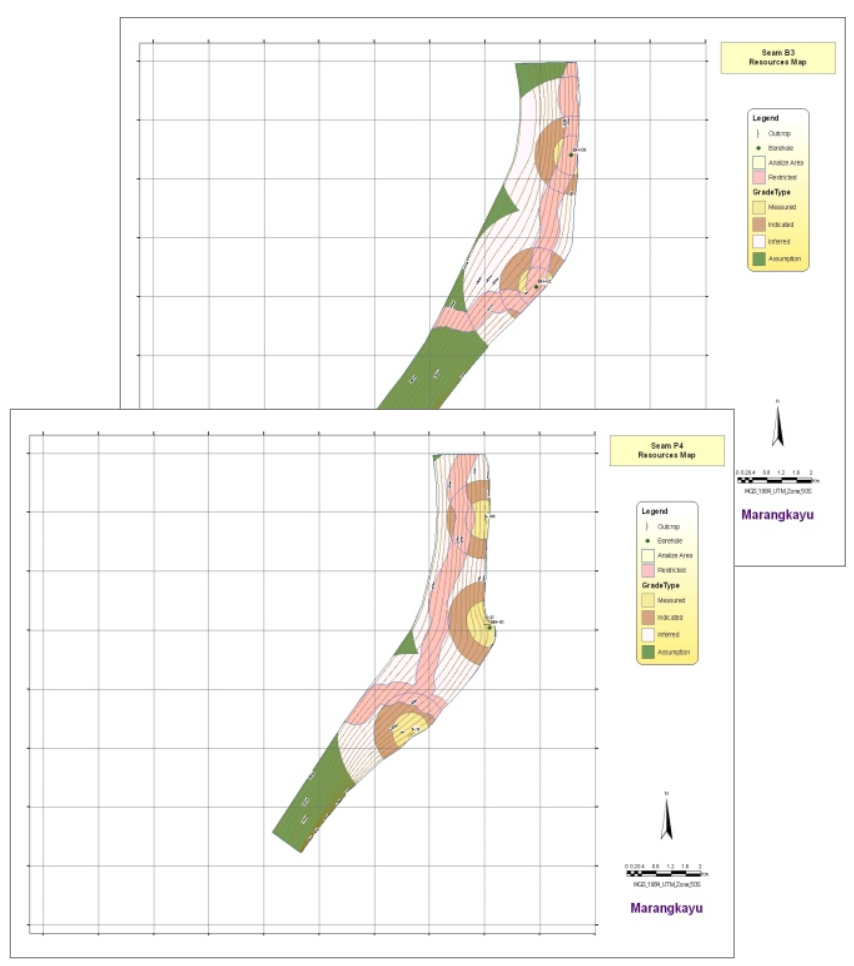

Gambar 7. Peta sumber daya batubara lapisan B3 dan P4 
Tabel 2. Jumlah perhitungan sumber daya dan cadangan daerah Marangkayu

\begin{tabular}{|c|c|c|c|c|c|c|c|c|}
\hline \multirow[b]{2}{*}{ Area } & \multirow[b]{2}{*}{ Seam } & \multirow{2}{*}{$\begin{array}{c}\text { Tebal } \\
\text { Rata- } \\
\text { rata } \\
\text { (m) }\end{array}$} & \multicolumn{3}{|c|}{ Sumberdaya $(\mathrm{Jt})^{*}$} & \multicolumn{3}{|c|}{ Cadangan $(\mathrm{Jt})^{*}$} \\
\hline & & & Mineable & Restricted & Total & $\begin{array}{l}\text { Open } \\
\text { Cut }\end{array}$ & $\begin{array}{l}\text { Under } \\
\text { ground }\end{array}$ & Total \\
\hline \multirow{8}{*}{ Marangkayu } & $B 10$ & 1,25 & 13,330 & 635 & 13,965 & 11,996 & 0 & 11,996 \\
\hline & 82 & 0.9 & 18.287 & 5,940 & 24.227 & 4,159 & 6,831 & 10,990 \\
\hline & B3 & 0,71 & 34,939 & 4,423 & 39.362 & 7,689 & 13,199 & 20,888 \\
\hline & B6 & 1.1 & 31.221 & 2.051 & 33.272 & 8,116 & 11,104 & 19,220 \\
\hline & 89 & 2 & 35,390 & 941 & 36.331 & 29.373 & 1.375 & 30.748 \\
\hline & P3 & 0.9 & 17.435 & 5,879 & 23.314 & 6,264 & 5.234 & 11,498 \\
\hline & P4 & 1,3 & 25,658 & 8,832 & 34,490 & 8,937 & 7,865 & 16,802 \\
\hline & & & 176,260 & 28,701 & 204,961 & 76,534 & 45,608 & 122,142 \\
\hline
\end{tabular}

\section{Perhitungan Sumber Daya dan Cadangan Batubara}

Perhitungan sumber daya dan cadangan batubara daerah Marangkayu juga memperhitungkan daerah terbatas (Restricted Area). Perhitungan dengan CRRES menyertakan beberapa parameter perhitungan seperti Mask Polygon (data poligon yang menjadi acuan perhitungan, umumnya merupakan poligon seam batubara), Specific Gravity (perbandingan besaran nilai massa terhadap volume), Safety (tingkat perbandingan recovery open pit terhadap underground), Interval (representasi jarak perhitungan kedalaman), Level From (titik ketinggian dimulainya perhitungan) dan Level To (titik kedalaman diakhirinya perhitungan). Jumlah perhitungan sumberdaya dan cadangan daerah ini dapat dilihat pada Tabel 2.

Perhitungan sampai dengan kedalaman -550 meter dari permukaan (elevasi) menghasilkan total sumber daya 204.961.000 ton, dengan sumber daya yang bisa ditambang (Mineable) adalah 176.260 .000 ton dan sumber daya tidak bisa ditambang (Restricted) sebesar 28.701.000 ton. Pemodelan geologi ini juga menghasilkan peta-peta dan tampilan tiga dimensi yang lebih dapat memvisualisasikan lapisan batubara daerah Marangkayu secara lebih rinci.

\section{KESIMPULAN DAN SARAN}

Hasil pemodelan geologi batubara daerah kajian Marangkayu memberikan hasil yang lebih dapat dipahami melalui penyertaan peta-peta dan hasil visualisasi dalam 3D. Pemodelan geologi menggunakan CRRES dapat membantu dalam penentuan daerah prospek yang lebih rinci dengan melakukan beberapa proses overlay atau tumpang tindih data yang tersedia.

CRRES akan sangat membantu untuk perhitungan sumberdaya dan cadangan batubara hasil penelitian PSDG, oleh karena itu sangat disarankan untuk melakukan penambahan pemodelan geologi daerah penelitian batubara yang lain.

\section{UCAPAN TERIMAKASIH}

Penulis mengucapkan terima kasih kepada Kepala Sub Bidang Pengembangan Informasi dan Kepala Sub Bidang Keprospekan yang sudah memberikan kesempatan untuk bisa menulis dalam buletin ini. Terima kasih juga kepada Irfan Ostman ST atas masukannya tentang dasardasar GIS. 


\section{MAKALAH ILMIAH}

\section{DAFTAR PUSTAKA}

Anonim,Peta Isopach, http://duniamigas.wordpress.com/2008/09/21/subsurface-mapping/ diakses tanggal 24 Oktober 2012

Anonim,SNI 13-6011-1999 tentang Klasifikasi Sumber Daya dan Cadangan Batubara, Badan Standarisasi Nasional

Anonim,Tim Inventarisasi Batubara Bersistem, Sub-Dit Batubara, 2002. Inventarisasi Endapan Batubara Bersistem Di Daerah Marangkayu dan Sekitarnya, Kabupaten Kutai Kertanegara, Propinsi Kalimantan Timur, Bandung

Wikipedia, ArcGIS, http://en.wikipedia.org/wiki/ArcGIS diakses tanggal 24 Oktober 2012

Wikipedia,Geologic Modelling, http://en.wikipedia.org/wiki/Geologic_modelling diakses tanggal 1 November 2012 